\title{
A CHAPTER OF THE MORAL HISTORY OF LONDON: AN INTERVIEW WITH BRIDGET O'CONNOR
}

\author{
Alberto Lázaro. Universidad de Alcalá
}

Bridget O'Connor is a young English fiction writer who has successfully published two collections of short stories, Here Comes John (1993) and Tell Her You Love Her (1997). Her stories introduce a great variety of voices: women or men of all ages and from many different social, cultural and professional background. However, many of them are first-person narratives involving a very peculiar character, young or middle-age, who generally lives in a city, London, and leads a lonely, boring and frustrating life. They make up a group of losers and drop-outs, characters who are socially, professionally or sexually doomed. This does not mean that Bridget O'Connor always adopts a depressing tone for her sad stories. On the contrary, every now and then, especially in the second volume, there is a touch of vibrant mordant humour associated with a satiric intention. The grotesque exaggerations, the suggestive idiom and the effective ironies designed to ridicule the characters' obsessions and follies often produce some comic passages. These amusing elements are cleverly juxtaposed to other more gloomy and sometimes tender images.

The immediacy and economy in her narrative brings to light one of the main virtues of her style. Everywhere the description and evocation have a precision, economy and sensitiveness which constitutes the reality of the books' style. Nothing is wasted. Every word and every detail are significant and necessary to create and evoke the appropriate mood. The descriptions are accurate, full of images which appeal to all our senses. There are credible dialogues in which the characters use a type of language which is appropriate to the situation, age or social status. Very often, style and purpose are closely knit in her stories. And all this clearly demonstrates her mastery of the genre.

Bridget O'Connor was interviewed in Alcalá de Henares (Madrid) on 19 February 1999, during a course on contemporary British writing, organised by the Department of Modern Philology of the University of Alcalá and the British Council (Madrid).

Alberto Lázaro - First of all, I'd like to ask you a general question. Your first collection of short stories appeared in 1993, when you were in your thirties. How did you happen to start writing? When do you first start thinking of yourself as a writer?

Bridget O'Connor - I probably started thinking of myself as a writer when I had my first story published. Before then I just hoped I would become a writer. That was when I was 25 or 26 and I had a story in an anthology and simultaneously in another book. However, I always 
wanted to write. When I was a child I used to draw cartoons and write stories. I was one of those children at school English teachers love. In my case, I had a sarcastic and playful teacher, who paid attention to my writings. He used to read my stories out, not because he thought they were good, but to display my ambition.

Sometimes he was very supportive, but sometimes I could feel malicious enjoyment. But even so, his comments were a great encouragement to me. Then, when I was at Lancaster University, I took a creative writing module. After that, I had a couple of stories published and I won a competition in a London magazine. Then things happened very quickly because a publisher rang me up and offered me a book contract. It was a wonderful thing to happen. Well I think it is an average story of how to be a writer: a lucky break and then a series of coincidences.

A.L. - Why did you decide to write short stories rather than other literary forms?

B.O. - Well, I didn't really decide, I just did. I didn't really choose a form. I knew I couldn't write poetry and I didn't really imagine ever writing a novel and I still haven't. So, maybe the short form was more natural to me. I just continued doing the same as I did when I was a child. I always enjoyed writing short stories.

A.L. - The short story has traditionally been considered a minor literary form in Britain, what do you think of the situation of the short story in Britain today?

B.O. - I think it is very dual. The short story form is admired and yet there is a great deal of pressure to move on from being a short story writer and to become a "proper" writer, which is a novel writer. Although in England people love short stories, it is not really reflected in a kind of status way. It is still seen as a kind of apprenticeship to the longer form, which is the novel. Obviously editors always welcome a new collection of those great successful writers, like William Trevor. But for young writers -under forty- is difficult to make a living being a short story writer. It doesn't seem to have the same kick as if you combine the publication of short stories with novels. It is difficult to become stable as a writer if you just write short stories. Only a few good writers can manage that.

A.L. - Malcolm Bradbury, in his edition of The Penguin Book of Modem British Short Stories, said that the short story may be the most difficult form of prose narrative and he called this genre "the lyric poem of modern fictional prose". Do you agree with this opinion?

B.O. - I do and I don't, because the short story is the short story honestly. I don't think it should pretend to be anything else. And if he refers to the supposed concentration of feelings and themes of the short story, I think that short stories don't have to be concentrated, concise or tight; they can be long, baggy, under, open-ended, like a ramble almost.

A.L. - In your two volumes we can appreciate a great variety of stories: satirical studies of contemporary vices, stories of action and more meditative tales; there is also a great variety of voices narrating these stories. Do you plan this variety or it comes naturally as a way of reflecting the variety of human life?

B.O. - No, I am not really conscious of making a decision. Having said that, when I wrote the first collection I hoped that the things I had in my drawer were good enough for the volume. In that way it was like a cooking pot with many different things in it. But the second collection was different because I had no plan for it, only a deadline. I might have started trying to have a 
variety of voices or narrators, but that is a very difficult thing to do. Hopefully what you do is either follow a theme all the way through or set one voice up against another.

A.L. - Despite this variety of situations and voices, the world you describe in your stories is very often an urban world full of anguished lonely characters, leading a frustrating life. What are the sources you draw on for your portraits of the contemporary social scene?

B.O. - Maybe because London, like any other metropolitan city, is so crowded, it is easy to find a character there with a story who serves to ilustrate the isolation of urban life as well as its crowdedness.

A.L. - Some scenes are very realistic. Are they based on your own experiences? Have you witnessed scenes like those?

B.O.: No, I've made them up obviously. However, I have seen things just in a normal everyday life, specially in the areas I've lived in - in North London. I live in a "poor" borough so it has its fair share of unhappy and lonely people.

A.L. - Have you ever described a situation of which you had no experience at all?

B.O. - Yes, often. Specially when I write from a male point of view. In these cases I have to guess and hope to get the tone right and find some colour to the situation, but not really in too documentary a fashion. I think it's a good thing to be bold and to reach outside your own experience.

A.L. - How much do you model your characters on real people, on people you know?

B.O. - Sometimes I do. I am very interested in describing friendships and other personal relationships, and the way history or time changes that, the way they age together. And I do have lots of friends who have been together for many years with very interesting and intense lives, and I adapt some of their experiences for my fiction. I do write about these friends every now and again, but of course they are disguised. In fact, there is nobody real in my tales, just bits of people. Some of these friends have said "Oh, that's me in the story, isn't it?" and sometimes it is and sometimes it just isn't. Lots of people might identify with a particular way of being in a story, because it is urban and it has a contemporary theme and they live a similar kind of life.

A.L. - How do you name your characters?

B.O. - Some of the characters, who I hope aren't very real, have different names. In my age group there are lots of people called Mick, Len and Den, which were popular names when I was growing; but names can date a book in a negative way. To get round that, I look for names which are popular now or which have a timeless quality. Choosing the right name is very important because sometimes it helps when you create the character; you can see the person practically through the name.

A.L. - What about the language they use in the story? Do you research for your stories?

B.O. - I listen and I read many magazines, and that's very helpful. I don't think I deliberately look for special words or idioms. If you want to catch a popular flavour, it is a good idea to listen to various different medias or to read different kinds of magazines. I also walk around a lot and I'm always on buses and trains, being nosey. 
A.B. - Many of your stories are about women's lives. Do you feel more comfortable when you write about female protagonists?

B.O. - It doesn't make much difference really. I don't think often about whether I'm going to write from a male's point of view of a female's point of view. I don't feel as if I am really using a character to talk about a particular point of view about gender. Sometimes it is more about the story; it's character-led, but not gender-led. I feel equally as comfortable really. Sometimes I worry about having the same kind of female voice in a first person, and I think a male one is slightly better, because it's like a new mood. It is very easy to adopt a combating tone in a first person from a woman's point of view; and I try to avoid that sometimes, because to speak like an angry woman can be like a trap.

A.L. - The inevitable question. Do you describe yourself in any of your characters?

B.O. - No, I just may introduce some personal experiences. For example, I was robbed a few years ago and it was a big shock. In "Hard Times", a story I wrote for the second collection, Tell Her You Love Her, I introduced a character with a similar experience who feels exposed at and very vulnerable since then. And that was true to me at that time. So this story is autobiographical in that it happened. Like the young girl of the story I was stupidly going to a cash point, I got robbed at a knife point and it was a big shock. But I do not really tend to do things like that, though I did think it was interesting the way it made me feel.

A.L. - I noticed some satiric intention in your stories. Do you try to denounce or to laugh at some particular defects, attitudes or behaviour of contemporary life?

B.O. - Yes, I think so. I tend to criticise common vices and follies, my own and other people's, like self-importance, pretension, hypocrisy or lying to oneself. Sometimes, it is vanity, like in "Hearts" with a vain jealous woman who doesn't love anybody and won't let them love. Similarly, "Enquiries (General)" is about self-knowledge, almost pretending not to have self-knowledge, not to be aware, when you know very clearly what your motives are.

A.L. - I think that most of your tales are stories of frustration, disenchantment and disaffection. They deal with failed personal and professional life. They remind me of James Joyce's Dubliners with its description of paralysis. Would you agree with that?

B.O. - I love vivid comparisons, of course. I love the idea that one of the central themes of my stories would be paralysis. I think that sounds true to the characters in several stories, where they long to escape and they try to, but they eventually go nowhere.

A.L. - If your stories are meant to show the paralysis that London suffers, what causes this paralysis?

B.O. - I think it is family; having to be born into a family you are born, having to be part of the social group; you have an ordained role. Just the weight of living in a city can be a little overwhelming. There is loneliness and at the same time many people bumping up against each other.

A.L. - Despite all these serious topics and sad lives, one can sometimes feel a comic touch, specially in the second volume Tell Her You Love Her. How important is humour in your stories?

B.O. - Well, I don't know if it is really a virtue to be seen as humorous. But I can't help it. In some of the stories you'd need to have humour in order to tell the tale in the voice you want 
to, with a slightly ironic or wry tone. So, sometimes you are being led for humour in a way you perhaps don't want to go. Humour is very important, but I'm trying to fight off my worst excesses of joke telling -making a point of telling a joke is a terrible fault.

A.L. - What authors have you learnt most from?

B.O. - First, there are all those authors you love and try to understand when you are growing up, such as James Joyce, Samuel Beckett, Thomas Hardy, Katherine Mansfield. I also like J. M. Coetzee. From them I have learnt how it is important as a story-teller to have a complete world view. Each writer has their own world, but the writer has to control that world. You create, not just the character but the world the character inhabits and the rules which are only applicable to that particular story. And all this without letting yourself be seen in the story.

A.L. - Did any other fiction writer influence you technically?

B.O. - Yes, I can think of E. Annie Proux, the author of such wonderful novels as Postcards, The Shipping News, or Accordion Crimes. And also Toni Morrison's writing, her style, her language.

A.L. - Most of your stories seem to follow traditional narrative techniques. There are, however, some experimental tales, like "Lenkas Wardrobe" - a metafictional story, a parody of detective fiction very much in tune with contemporary postmodernist novels. How interested are you in experimentation, in finding new ways of telling stories?

B.O. - Well, I'm very interested. But, to be honest, I've always loved "story" and I'm not really into the form, breaking up pages, having strange symbols, or doing anything extraexperimental. I'm interested in finding different ways of telling a story, in not staying the same myself, rather than in different ways of short story structure.

A.L. - What is your process of writing? Before you begin to write a story, do you plan the overall structure, the main features of the characters and the ending?

B.O. - At the moment I try to write everyday. Sometimes I start with a single image. Sometimes I go with the title; the tone of the title guides me through the story. On the whole, it is not a very pleasant process. I have read lots of things about writers who love going to the desk and write, but sometimes I do find it difficult. However, when you are involved in something, I do not think there can be anything better -you don't realise how many hours are going by and that's wonderful. But that is very very rare.

A.L. - Would you agree with the cliche that genius is $90 \%$ perspiration and $10 \%$ inspiration?

B.O. - Well, I think most of the people who are very successful work really hard, so yes I do. The kind of writer I'd love to be is this kind of writer who has this amazing routine: gets up at five o'clock in the morning, writes for many hours, has a very spare breakfast, goes for a run, comes back and reads a book, goes for a walk, and does more writing in the afternoon. But it is never ever like that. It is usually full of whining and moaning.

A.L. - How does inspiration happen to you?

B.O. - Listening and walking around. Overhearing what people are saying. Or a sensual experience like smelling or tasting something. Or that sort of thing where you've been thinking about something for a while and then suddenly you see how you can make it into fiction; not that it was your intention. 
A.L. - It is interesting that you mention the importance of sensual experience in your writing, because I've noticed a continuing presence of the senses in your descriptions, specially the sense of smell. When you describe a scene, which senses do you like to appeal to?

B.O. - I'd love it to be eyes, hearing second, and smell should be way down the list - it's not a very glamorous sense. But I think the sense of smell is probably the first, though I don't know why that should be really; I don't think I've got a particularly refined one.

A.L. - Of all the stories you have written, which is your favourite one?

B.O. - In the first collection I like "Love Jobs", though I don't really know why. In the second one, it is "Enquiries (General)", because I think the girl is a heart-breaking character, though she has a lovely time at the end. I like "Shop Talk" as well, because it reminds me of working in shops, being bored and having a terrible time; nothing happens and yet the day has been packed with feeling.

A.L. - And what is the best story you never wrote?

B.0. - I do love Waiting for the Barbarians by J. M. Coetzee, but that's a novel. I also love a story by Frank O'Connor entitled "Guests of a Nation", because it's got a wonderful tone. It's about two prisoners of the I.R.A., two Englishmen who are captured by very benign guards in Ireland, and they are the guests of the nation. They play cards all night, they talk like friends all the time, and they have this lovely time, as prisoners. And then the order comes that they have to be shot because somebody has been shot in retaliation. The narrator feels awful because they were already friends; if he had known that they were going to be killed, he wouldn't have befriended them. And there is this wonderful shocking scene at the end, where they are taken across to be killed in the marsh. It's a wonderful story about friendship.

A.L. - Some writers are very sensitive to criticism. Have you been much affected yourself by critics?

B.O. - Yes, of course. As a new writer, you think that everybody should like you. It's ridiculous and childish really, because you've written something and it is there to be criticised. I suppose you've just got to accept it. Of course, it hurts, specially if you feel that what they say is true; if they are telling lies you can just be angry.

A.L. - What are you working on now?

B.O. - I've written another collection of short stories. Most of the stories in this new collection are less naturalistic and more surreal, less first-person and more third-person, and lots of the same things about being obsessed and people being debilitated by love. I am also writing a novel.

Thank you very much for your patience and time. 